\title{
Diarrheagenic pathogens in adults attending a hospital in Singapore
}

\author{
Man Ling Chau', Sri Harminda Pahm Hartantyo', Min Yap', Joanne Su Lin Kang', Kyaw Thu Aung', \\ Ramona Alikiiteaga Gutiérrez ${ }^{1 *}$, Lee Ching $\mathrm{Ng}^{1}$, Clarence C. Tam ${ }^{2,3}$ and Timothy Barkham ${ }^{4}$
}

\begin{abstract}
Background: Singapore's diarrhoeal notification system is based on specific pathogens. Official data may thus be skewed towards notifiable diseases. Limited information is available on the profiles of aetiological agents responsible for acute gastroenteritis (AGE) cases, especially among the adult population. To understand the frequency and distribution of potential causative agents of diarrheal disease in Singapore, we screened adults' stool samples collected from a large public hospital.

Methods: The stool samples were screened for 18 diarrheagenic pathogens using a combination of commercial multiplex polymerase chain reaction (PCR), in-house singleplex PCR and immunochromatographic assays. One hundred adult faecal samples that were collected from October 2013 to January 2014 for routine diagnostic purposes and submitted for culture at Tan Tock Seng Hospital, Singapore were used.

Results: Pathogens were detected in $32 \%$ of the samples. The predominant organisms encountered were norovirus genogroup II (11\%), Aeromonas spp. (9\%) and Campylobacter spp. (5\%). One sample was positive for both verocytotoxigenic E. coli (VTEC) and E. coli O157:H7. Two other samples were positive for VTEC only, and one other sample was positive for E. coli 0157:H7 only. Astrovirus, C. perfringens, Shigella spp. and toxigenic C. difficile were each detected in $2 \%$ of the samples. Cryptosporidium parvum, Giardia lamblia, group A rotavirus, Salmonella spp. and Vibrio spp. were each detected in $1 \%$ of the samples. No L. monocytogenes, Y. enterocolitica, enteric adenovirus, or norovirus genogroup I were detected.

Conclusion: Our preliminary findings suggest that pathogens causing non-notifiable diseases might have contributed considerably to the adult hospitalised AGE cases. However, as the samples were from an adult hospital, the data obtained may not be representative of the whole community. Thus, a larger study to collect clinical samples and risk exposure data from primary healthcare clinics and children hospital is planned for, to gain a more holistic perspective on the epidemiology of AGE in Singapore. A larger study may also offer valuable insights for improving the approach of microbiological surveillance of food, as well as strategizing inspection efforts along the food supply chain by public health authorities.
\end{abstract}

Keywords: Diarrhoea, Pathogens, Adult hospital patients, Singapore, Acute gastroenteritis, Foodborne

\section{Background}

Acute gastroenteritis (AGE) is caused by a wide range of enteric bacteria, viruses, protozoa and helminths [1]. Although mortality from AGE is lower in high-income countries, morbidity is still substantial $[1,2]$. It is estimated that $15 \%$ of the population in the United States and $27 \%$ of the population in the United Kingdom are

\footnotetext{
*Correspondence: Ramona_GUTIERREZ@nea.gov.sg

${ }^{1}$ Environmental Health Institute, National Environment Agency, 11 Biopolis

Way, \#04-03/04, Helios Block, Singapore 138667, Singapore

Full list of author information is available at the end of the article
}

affected by AGE per year [3, 4]. In Singapore, the incidence of polyclinic attendances due to acute diarrhoea was $2.2 \%$ of the population in 2009 compared to $2.5 \%$ of the population in $2013[5,6]$. National surveillance statistics show that the incidence of food poisoning outbreaks (two or more cases epidemiologically linked to a common source) was 4.0 per 100,000 population in 2009 compared to 4.6 per 100,000 population in $2013[5,6]$. These reported numbers are likely to be an under-estimation of the disease burden, as general acute gastroenteritis (AGE) 
is not a legally notifiable disease in Singapore, with the exception of specific diseases such as salmonellosis, campylobacteriosis, cholera, enteric fever and hepatitis [7].

Given the lack of information on aetiological agents causing AGE in Singaporean adults, a preliminary study was conducted to determine the frequency and distribution of diarrheagenic pathogens in adults' residual stool samples collected from a hospital in Singapore. This hospital was chosen as it is one of the largest public hospitals in Singapore [8]. Between March 2014 and February 2015, it had a total number of 2,596 admissions due to gastroenteritis, of which approximately $40 \%$ of the gastroenteritis cases were with complications $[9,10]$. It is aimed that through this pilot study, preliminary data can be obtained to guide us in the design of a potentially larger multi-site study to understand the epidemiology of AGE in Singapore.

\section{Methods}

\section{Specimens}

One hundred anonymised faecal samples from adult patients in Tan Tock Seng Hospital, between October 2013 and January 2014, were used. These were residual samples leftover from samples submitted as part of routine adult patient investigation. Only samples submitted within 3 days of admission were used to exclude samples from nosocomial diarrheal cases. No further clinical data were obtained. Samples were kept frozen at $-80{ }^{\circ} \mathrm{C}$ and transported on ice to the laboratory at the Environmental Health Institute (EHI) of the National Environment Agency (NEA), Singapore. Samples were then stored at $-80{ }^{\circ} \mathrm{C}$ until laboratory analysis. Ethical approval was granted by the Institutional Review Board of the National Healthcare Group, Singapore. Samples were analysed for the presence of 18 diarrheagenic pathogens using a combination of nucleic acid tests and immunochromatographic assays, as illustrated in Table 1.

\section{Nucleic acid tests}

A $10 \%$ suspension of each faecal sample was prepared using Butterfield's Phosphate Buffer (3 M, Minnesota). Three-hundred microlitres of each $10 \%$ faecal suspension were heated at $100{ }^{\circ} \mathrm{C}$ for $10 \mathrm{~min}$. Upon cooling to ambient temperature, the suspension was centrifuged for $10 \mathrm{~min}$ at $13,000 \mathrm{rpm}$ and $200 \mu \mathrm{l}$ of the supernatant were obtained for simultaneous extraction of bacterial and viral nucleic acids using Ribo_spin vRD kit (Geneall, Korea) according to the manufacturer's instructions. First strand cDNA was synthesized using Maxima $\mathrm{H}$ Minus First Strand cDNA synthesis kit (ThermoScientific, Lithuania) using a random hexamer primer according to the manufacturer's instructions. Nucleic acids obtained were subsequently used for the screening of Aeromonas spp., Campylobacter spp., Clostridium difficile toxin B gene, Clostridium perfringens, Shigella spp., verocytotoxigenic Escherichia coli, Escherichia coli O157:H7, Salmonella spp., Yersinia enterocolitica, Vibrio spp., astrovirus, group A rotavirus, norovirus genogroup I, norovirus genotype II and enteric adenovirus using Seeplex Diarrhoea ACE system (Seegene, Korea) according to the manufacturer's instructions. The same samples were also screened for Aeromonas spp., Campylobacter spp., Salmonella spp. and Listeria monocytogenes using in-house singleplex PCR assays with published primers (Table 2). In each singleplex PCR, $5 \mu \mathrm{l}$ of the sample DNA were added to a master-mix consisting of 1X Q5 reaction buffer (New England Biolabs, Massachusetts), $200 \mu \mathrm{M}$ of dNTPs ( $1^{\text {st }}$ BASE, Singapore), $0.5 \mu \mathrm{M}$ of the respective forward and reverse primer (Integrated DNA Technologies, Singapore), 1U of Q5 Hot Start High Fidelity DNA polymerase (New England Biolabs, Massachusetts) and nuclease free water to attain a final volume of $50 \mu \mathrm{l}$. For the screening of Aeromonas spp, Campylobacter spp. and Salmonella spp., amplification was conducted in a thermal cycler (ABI Systems GeneAmp PCR system 9700) with the following temperature ramping: $98{ }^{\circ} \mathrm{C}$ for $30 \mathrm{~s}$, followed by 35 cycles of $98^{\circ} \mathrm{C}$ for $10 \mathrm{~s}, 62^{\circ} \mathrm{C}$ for $30 \mathrm{~s}, 72{ }^{\circ} \mathrm{C}$ for $30 \mathrm{~s}$, and finally $72{ }^{\circ} \mathrm{C}$ for $10 \mathrm{~min}$. For the screening of $L$. monocytogenes, the following temperature ramping was performed: $98{ }^{\circ} \mathrm{C}$ for $30 \mathrm{~s}$, followed by 35 cycles of $98{ }^{\circ} \mathrm{C}$ for $10 \mathrm{~s}, 61{ }^{\circ} \mathrm{C}$ for $30 \mathrm{~s}$, $72{ }^{\circ} \mathrm{C}$ for $30 \mathrm{~s}$, and finally $72{ }^{\circ} \mathrm{C}$ for $10 \mathrm{~min}$. All PCR amplified product sizes were analysed using QIAxcel DNA screening kit (Qiagen, Hilden). Sequencing of the singleplex PCR products was performed by a commercial company (AITbiotech Pte Ltd, Singapore) using BigDye Terminator Cycle Sequencing kit (Applied Biosystems, USA). Nucleotide sequences were then aligned using SeqMan Pro software (DNASTAR, US) and compared against the online BLAST database (http:// blast.st-va.ncbi.nlm.nih.gov/Blast.cgi) to confirm the presence of the targeted pathogens.

\section{Immunochromatography assays}

A $50 \%$ suspension of each faecal sample was prepared using Butterfield's Phosphate Buffer (3 M, Minnesota). Suspensions were screened for the presence of Cryptosporidium parvum and Giardia lamblia using RIDA QUICK Cryptosporidium/ Giardia Combi kit (R-Biopharm AG, Germany), as well as Clostridium difficile glutamate dehydrogenase (GDH) using RIDA QUICK Clostridium difficile GDH kit (R-Biopharm AG, Germany) according to the manufacturer's instructions. xSamples which were positive for Clostridium difficile GDH underwent further screening for toxins using RIDA QUICK Clostridium difficile toxin A/B kit (RBiopharm AG, Germany) according to the manufacturer's instructions. 
Table 1 Positivity rate (\%) of targeted organisms detected in faecal samples $(n=100)$ by respective screening methods

\begin{tabular}{|c|c|c|}
\hline Organism(s) & Screening method & $\%$ positivity \\
\hline Norovirus GII & Seeplex diarrhoea ACE system & 11 \\
\hline Aeromonas spp. & Seeplex diarrhoea ACE system,In-house singleplex PCR system & $9^{a}$ \\
\hline Campylobacter spp. & Seeplex diarrhoea ACE system,In-house singleplex PCR system & $5^{\mathrm{b}}$ \\
\hline Astrovirus & Seeplex diarrhoea ACE system & 2 \\
\hline C. perfringens & Seeplex diarrhoea ACE system & 2 \\
\hline Shigella spp. & Seeplex diarrhoea ACE system & 2 \\
\hline Toxigenic C. difficile & $\begin{array}{l}\text { Seeplex diarrhoea ACE system,RIDA QUICK C. difficile GDH kit, } \\
\text { RIDA QUICK C. difficile toxin A/B kit }\end{array}$ & $2^{c}$ \\
\hline Verocytotoxigenic E. coli (VTEC) & Seeplex diarrhoea ACE system & 2 \\
\hline Cryptosporidium parvum & RIDA QUICK Cryptosporidium/ Giardia combi kit & 1 \\
\hline E. coli O157:H7 & Seeplex diarrhoea ACE system & 1 \\
\hline Giardia lamblia & RIDA QUICK Cryptosporidium/ Giardia combi kit & 1 \\
\hline Group A rotavirus & Seeplex diarrhoea ACE system & 1 \\
\hline Salmonella spp. & Seeplex diarrhoea ACE system,In-house singleplex PCR system & $1^{d}$ \\
\hline Vibrio spp. & Seeplex diarrhoea ACE system & 1 \\
\hline VTEC and E. coli O157:H7 & Seeplex diarrhoea ACE system & 1 \\
\hline Enteric adenovirus & Seeplex diarrhoea ACE system & 0 \\
\hline L. monocytogenes & In-house singleplex PCR & 0 \\
\hline Norovirus Gl & Seeplex diarrhoea ACE system & 0 \\
\hline Y. enterocolitica & Seeplex diarrhoea ACE system & 0 \\
\hline
\end{tabular}

${ }^{a}$ Nine samples were detected positive for Aeromonas spp. using Seeplex diarrhoea ACE system but five were detected positive by in-house singleplex PCR ${ }^{\mathrm{b}}$ Five samples were detected positive for Campylobacter spp. using in-house singleplex PCR but none were detected positive by Seeplex diarrhoea ACE system ${ }^{\mathrm{C}}$ Two samples were detected positive for both Clostridium GDH and Clostridium toxin A/B using RIDA Quick lateral flow kits, and for Clostridium toxin B using Seeplex diarrhoea ACE system

${ }^{\mathrm{d} O n e}$ sample was detected positive for Salmonella spp. by both in-house singleplex PCR and Seeplex diarrhoea ACE system

\section{Isolation and characterisation of pathogens}

Only one Salmonella and one Vibrio cholerae isolate were successfully recovered from PCR-positive samples. The isolation of Aeromonas spp, Shigella spp. and verocytotoxigenic E. coli (VTEC) were unsuccessful. Their isolation and characterisation procedures are as described below.
Isolation and characterisation of Salmonella spp.

One gram of each faecal sample that was tested positive for Salmonella spp. using Seeplex Diarrhoea ACE system was suspended into $9 \mathrm{ml}$ of the Universal Pre-enrichment Broth (Acumedia, Michigan) and incubated at $37{ }^{\circ} \mathrm{C}$ for $24 \mathrm{~h}$. One millilitre of the enriched broth was then sub-

Table 2 Primers used for the detection of Campylobacter spp., Salmonella spp. and Listeria monocytogenes, as well as the detection and characterisation of Vibrio cholerae

\begin{tabular}{|c|c|c|c|c|c|c|}
\hline Parameter & $\begin{array}{l}\text { Target } \\
\text { gene }\end{array}$ & Forward primer (5-3) & Reverse primers $(5-3)$ & $\begin{array}{l}\text { Concentration } \\
(\mu \mathrm{M})\end{array}$ & Size(bp) & References \\
\hline Aeromonas spp. & 16 s rDNA & GGGAGTGCCTTCGGGAATCAGA & TCACCGCAACATTCTGATTTG & 0.5 & 356 & [14] \\
\hline Campylobacter spp. & 16 s rDNA & GGTGTAGGATGAGACTATATA & TTCCATCTGCCTCTCCCY & 0.5 & 439 & [54] \\
\hline Salmonella spp. & inva & ACAGTGCTCGTTTACGACCTGAAT & AGACGACTGGTACTGATCGATAAT & 0.5 & 244 & [55] \\
\hline Listeria monocytogenes & $\ln / A$ & ACGAGTAACGGGACAAATGC & CCCGACAGTGGTGCTAGATT & 0.5 & 800 & {$[56]$} \\
\hline V. cholerae & toxR & GAAGCTGCTCATGACATC & AAGATCAGGGTGGTTATTC & 0.01 & 275 & [57] \\
\hline $\begin{array}{l}\text { V. cholerae serogroup } \\
\text { O1 }\end{array}$ & Wbe (01) & GTTTCACTGAACAGATGGG & GGTCATCTGTAAGTACAAC & 0.05 & 192 & {$[15]$} \\
\hline $\begin{array}{l}\text { V. cholerae biotype (El } \\
\text { Tor) }\end{array}$ & $\operatorname{tcp} A$ & CACGATAAGAAAACCGGTCAAGAG & CGAAAGCACCTTCTTTCACGTTG & 0.05 & 451 & {$[58]$} \\
\hline \multirow{2}{*}{$\begin{array}{l}\text { V. cholerae virulence } \\
\text { genes }\end{array}$} & $\operatorname{ct} \times A$ & ACAGAGTGAGTACTTTGACC & ATACCATCCATATATTTGGGAG & 0.05 & 308 & [15] \\
\hline & $\operatorname{ct} \times B$ & ATGAGGCGTTTTATTATTCCATACAC & TACCAGGTAGTCAACATATAGATTCA & 0.05 & 128 & {$[59]$} \\
\hline
\end{tabular}


cultured into $9 \mathrm{ml}$ of the 2X Rappaport-Vassiliadis Enrichment Broth (Neogen, Michigan) and incubated at $42{ }^{\circ} \mathrm{C}$ for $24 \mathrm{~h}$. After incubation, a $10 \mu \mathrm{l}$ loopful of the enriched broth was sub-cultured onto Hektoen Enteric Agar (Oxoid, Hampshire). Presumptive green colonies with black centres on Hektoen Enteric Agar were confirmed using API 20E strips (bioMérieux, France). Serological groups of the isolates were determined using Wellcolex Colour Salmonella latex agglutination tests according to the manufacturer's instructions (Remel Europe, UK).

\section{Isolation and characterisation of Vibrio cholerae}

One gram of each faecal sample that tested positive for Vibrio spp. using Seeplex Diarrhoea ACE system was suspended into $9 \mathrm{ml}$ of the Universal Pre-enrichment Broth (Acumedia, Michigan) and incubated at $37{ }^{\circ} \mathrm{C}$ for $24 \mathrm{~h}$. After incubation, a $10 \mu \mathrm{l}$ loopful of the enriched broth was streaked onto Thiosulfate-Citrate-Bile SaltSucrose (TCBS) Agar (Oxoid, Hampshire). Presumptive large yellow colonies on TCBS were confirmed using API 20E strips (bioMérieux, France). Confirmation by serology was conducted using Vibrio cholerae $\mathrm{O} 1$ polyvalent antisera (Remel Europe, UK). DNA of the $V$. cholerae isolate was extracted using QIAamp DNA Mini Kit (Qiagen, Hilden) according to the manufacturer's instructions. The DNA was then used for confirmation of $V$. cholerae species, identification of serogroup and biotype, and presence of virulence genes $(\operatorname{ctx} A, \operatorname{ctx} B)$ by PCR, using published primers, as listed in Table 2. The composition of the master-mix included $1 \mathrm{X}$ Q5 reaction buffer (New England Biolabs, Massachusetts), $200 \mu \mathrm{M}$ of dNTPs ( $1^{\text {st }}$ BASE, Singapore), 1U of Q5 Hot Start High Fidelity DNA polymerase (New England Biolabs, Massachusetts), forward and reverse primers (Integrated DNA Technologies, Singapore) with concentrations listed in Table 2, $5 \mu \mathrm{l}$ of the sample DNA, and nuclease free water to attain a final volume of $50 \mu \mathrm{l}$. Amplification was performed in a thermal cycler (ABI Systems GeneAmp PCR system 9700) with the following temperature ramping: $98{ }^{\circ} \mathrm{C}$ for $30 \mathrm{~s}$, followed by 35 cycles of $98^{\circ} \mathrm{C}$ for $10 \mathrm{~s}, 60^{\circ} \mathrm{C}$ for $30 \mathrm{~s}, 72^{\circ}$ $\mathrm{C}$ for $30 \mathrm{~s}$, and finally $72^{\circ} \mathrm{C}$ for $10 \mathrm{~min}$. All PCR amplified product sizes were analysed using QIAxcel DNA high resolution kit (Qiagen, Hilden).

\section{Isolation of Aeromonas spp.}

When Aeromonas spp. were detected in faecal samples by the Seeplex Diarrhoea ACE system, $1 \mathrm{~g}$ portions were each suspended into $9 \mathrm{ml}$ of Universal Pre-enrichment Broth (Acumedia, Michigan) and Alkaline Peptone Water (FDA-BAM media formulation) [11]. The broths were incubated at $37^{\circ} \mathrm{C}$ for $24 \mathrm{~h}$. A $10 \mu \mathrm{l}$ loopful of each enriched broth was streaked onto SA agar (Himedia, India) and incubated at $30{ }^{\circ} \mathrm{C}$ for $24 \mathrm{~h}$. Starch hydrolysis was observed by flooding each incubated plate with $5 \mathrm{ml}$ of iodine solution (Oxoid, Hampshire). Presumptive yellow colonies with zones of clearing were confirmed using API 20E strips (bioMérieux, France).

\section{Isolation of Shigella spp.}

When Shigella spp. were detected by the Seeplex Diarrhoea ACE system, $1 \mathrm{~g}$ portions of the faecal samples were suspended into $9 \mathrm{ml}$ of Shigella broth (FDA-BAM media formulation) [12]. Isolation and confirmation were conducted based on procedures described in FDABAM Chapter 6 [13].

\section{Isolation of verocytotoxigenic E. coli (VTEC)}

When VTECs were detected by the Seeplex Diarrhoea ACE system, $1 \mathrm{~g}$ portions of the faecal samples were added into $9 \mathrm{ml}$ of the Universal Pre-enrichment Broth (Acumedia, Michigan) and incubated at $37{ }^{\circ} \mathrm{C}$ for $24 \mathrm{~h}$. A $10 \mu$ loopful of the enriched broth was sub-cultured onto Eosin Methylene Blue, Levine agar (Acumedia, Michigan) and incubated at $37{ }^{\circ} \mathrm{C}$ for $24 \mathrm{~h}$. Blue black colonies were confirmed as $E$. coli based on positive indole test reactions (Remel, Kansas). E. coli colonies were then screened for the presence of vtx 1 and/or vtx 2 genes using DEC PCR kit (Statens Serum Institut, Hillerød) according to the manufacturer's instructions.

\section{Statistical analysis}

The percentage of specimens positive for at least one of the 18 organisms tested for, as well as the percentage of specimens positive for each organism (inclusive of samples with co-detection of pathogens) were determined. Where specimens were positive for two or more organisms, the percentage of co-detection for each combination of organisms was determined.

\section{Results}

Thirty-two percent (32\%) of the faecal samples contained at least one of the 18 organisms screened for. Bacterial pathogens were detected in $21 \%$ of the samples, while viral and parasitic pathogens were detected in 14 and $2 \%$ of the samples respectively. A total of eight samples (8\%) were positive for more than one pathogen. The frequency of co-detection is shown in Table 3.

Table 1 shows the percentage of samples positive for each organism tested. The most frequently encountered organism was norovirus genogroup II (11\%), followed by Aeromonas spp. (9\%) and Campylobacter spp. (5\%). One sample (1\%) was PCR-positive for both VTEC and E. coli $\mathrm{O} 157: \mathrm{H7}$.

The Seeplex Diarrhoea ACE system and the in-house singleplex PCR showed consistent results for the screening of Salmonella spp.. However, the Seeplex Diarrhoea ACE system was unable to detect Campylobacter spp. in five samples that tested positive using the in-house 
Table 3 Co-detection of targeted organisms in faecal samples $(n=100)$

\begin{tabular}{ll}
\hline Pathogens co-detected in faecal samples & $\begin{array}{l}\text { \% faecal } \\
\text { samples }\end{array}$ \\
\hline Aeromonas spp., C. perfringens & 2 \\
Aeromonas spp., astrovirus & 1 \\
Campylobacter spp., norovirus GII & 1 \\
Campylobacter spp., group A rotavirus & 1 \\
Aeromonas spp., Salmonella spp., astrovirus & 1 \\
Aeromonas spp., Campylobacter spp., E. coli O157:H7 & 1 \\
Campylobacter spp., E. coli O157:H7, verocytotoxigenic E. & 1 \\
coli, norovirus Gll &
\end{tabular}

singleplex PCR. This may be due to the fact that Seeplex is designed to detect only $C$. jejuni and $C$. coli whereas the singleplex PCR is meant to target the Campylobacter genus. While Aeromonas spp. was detected in nine samples using the Seeplex Diarrhoea ACE system, only five samples were detected using the in-house singleplex PCR. This could be because Seeplex is designed to detect $A$. bivalvium, A. hydrophila, A. media, A. salmonicida, A. sobria, and $A$. veronii whereas the singleplex primers were designed based on the 16S rRNA gene region of A. hydrophila ATCC 7966 [14].

One Salmonella serogroup C and one Vibrio cholerae O1 El Tor were successfully recovered from PCRpositive samples. The $V$. cholerae isolate was found to be positive for $c t x A$ and $c t x B$ virulence genes, which affirm its genetic potential to produce cholera toxin [15], a protein responsible for causing profuse watery diarrhoea and vomiting [16].

\section{Discussion}

Due to the ease of access to healthcare facilities by the general public, acute gastroenteritis (AGE) is seldom life-threatening in Singapore. However, the disease burden could be further reduced by strategic control measures. National statistics obtained from foodborne outbreak investigations from 2009 to 2011 [17] revealed that $51.2 \%$ of the faecal samples obtained from cases contained pathogens, $75 \%$ of these being Salmonella spp.. Separately, a study conducted at a women's and children's hospital in Singapore [18] revealed that AGE represented 1.7 to $2.4 \%$ of paediatric admissions in 2003 and 2004, involving mainly children below 4 years old. The study reported that $81.4 \%$ of the acute diarrhoea cases were due to viral infections while $17.9 \%$ were attributed to bacterial infections, predominately due to Salmonella spp.. While that study provided valuable insights into the aetiology of AGE in children, there is still insufficient understanding of the aetiological agents contributing to non-outbreak-related adult AGE cases in Singapore. This may be due to a number of factors, such as the fact that hospitals do not routinely screen for a wide range of diarrheagenic pathogens, or that primary healthcare providers seldom submit faecal samples from diarrhoeal patients in the community for laboratory analysis.

In order to design a more comprehensive study to understand the epidemiology of AGE in Singapore, we have conducted this pilot study to obtain some preliminary data on the frequency and distribution of pathogens in adults' faecal samples collected from a hospital in Singapore. Our findings suggest that pathogens causing non-notifiable disease might contribute significantly to adult hospitalised AGE cases. However, as the samples analysed were from a hospital, the data obtained may not be representative of the country. With reference to other high-income countries, the positivity rate of pathogens determined in our study (32\%) is comparable with that in Australia, the U.S. and the U.K., but much lower than that in Germany [19-22]. In the U.S., it was estimated in 2011 that $44 \%$ of the hospitalised cases of all age groups due to domestically acquired foodborne illnesses were caused by known pathogens [22], predominately due to non-typhoidal Salmonella and norovirus [23]. In Australia, approximately $25 \%$ of the hospital diagnosed gastroenteritis cases of all age groups were attributed to known aetiological agents, in which Campylobacter and non-typhoidal Salmonella were identified as the leading causes [20]. In the U.K., pathogens were detected in $50 \%$ of patients of all age groups with infectious intestinal diseases who presented to general practitioners (GP) [19]. In contrast, a higher positivity rate of $82 \%$ was detected in hospitalised adults suffering from AGE in Germany [21]. The variations in the positivity rates among studies should however be interpreted with caution as they could be due to numerous factors such as differences in case definitions used, screening panels, assay methods, nature of AGE cases (community vs. hospital), dietary factors and demographic profiles (age in particular) among countries. Additionally, it is noteworthy that as diarrhoea is a non-specific symptom observed in many diseases, it is difficult to rule out diarrhoeal cases caused by non-infectious diseases without obtaining epidemiological information and a medical history.

The predominant pathogen detected in our study was norovirus genogroup II (11 \%). Norovirus is the leading cause of acute gastroenteritis (AGE) in many highincome countries such as the U.S., Australia and the U.K. [4, 20, 24]. Norovirus infection is highly contagious and can be transmitted through multiple routes, including through the ingestion of naturally contaminated food (such as salads, shellfish, water), or through person-toperson (e.g. aerosolised vomit) or environmental transmission (e.g. fomites) [25-30]. The positivity rate obtained in our study $(11 \%)$ is comparable with that of other studies conducted on AGE cases of all age groups in the U.K., 
Hong Kong S.A.R. and Taiwan [19, 30, 31]. From a global perspective, norovirus genogroup II genotype 4 (GII.4) is assessed to be responsible for most outbreaks and community cases of AGE and has been associated with an increased rate of hospitalisation and death during outbreaks based on data published between 1993 and 2011 [32]. Currently, screening of norovirus in adult diarrhoeal patients is not routinely performed in Singapore. Because there is no medical treatment for norovirus infection, the screening of norovirus may only offer limited benefits in clinical management. Nevertheless, it may be of public health value to combine epidemiological studies with further molecular characterisation of local norovirus strains, obtained from clinical and environmental sources, to determine the predominant modes of transmission. This may allow the design of relevant control measures and reduce the associated disease burden. Future work could also include the quantification of faecal viral loads using real-time reverse transcriptase PCR (RT-PCR). Indeed, as real time RT-PCR is able to detect low concentrations of norovirus, previous studies suggested the use of a suitable Cycle threshold $(\mathrm{Ct})$ value as a cut-off point to distinguish between asymptomatic norovirus carriage and norovirus infection based on Receiver-Operating Characteristics (ROC) analysis [33]. This would in turn help to guide operational efforts by public health agencies to control and minimise the societal burden of AGE caused by norovirus.

The prevalence of Aeromonas spp. (9\%) in this study was higher than that of other bacteria. Aeromonas spp., are widely distributed in the aquatic environment and have been isolated from many food types including meat, poultry, fish, seafood and vegetables [34]. A. hydrophila, A. caviae and $A$. veronii, in particular, are suspected of being emerging pathogens as they are capable of producing virulence factors even under cold temperatures [34] and may pose a potential hazard in chilled ready-to-eat food. However, their detection in clinical samples should be interpreted with caution as it may not always be associated with disease. A study conducted in Brazil showed a significant difference in the prevalence of Aeromonas spp. observed between out-patient diarrhoeal cases and healthy controls [35]. However, another study conducted in the U.K. cited that the detection rates of Aeromonas spp. in diarrhoeal patients (presented to community practitioners) and asymptomatic controls were similar [36]. Unfortunately, as healthy controls were not included in our study, and as the recovery of Aeromonas isolates from the frozen samples for speciation and virotyping was unsuccessful, the actual contribution of Aeromonas spp. to AGE symptoms cannot be ascertained further.

Verotoxigenic E. coli (VTEC), also known as Shiga toxin-producing $E$. coli (STEC), refers to a group of diarrheagenic $E$. coli which produces stx 1 and/or stx 2 toxins [37]. Enterohaemorrhagic E. coli (EHEC), a virotype of
VTEC, may cause illness in humans [38]. As EHEC may cause bloody diarrhoea and potentially haemolytic uremic syndrome in severe cases [37], it is not surprising to detect their presence in hospitalised cases. In our study, one faecal sample was PCR-positive for both VTEC and E. coli O157:H7 although it was not detected or reported by the diagnostic laboratory. E. coli $\mathrm{O} 157: \mathrm{H} 7$ is a serotype which has frequently been encountered in clinical cases worldwide [37]. Other EHEC serotypes known to be associated with foodborne diseases include $\mathrm{O} 26, \mathrm{O} 45, \mathrm{O} 91, \mathrm{O} 103$, O104, O111, O121 and O145 [38]. In 2011, serotype O104:H4 caused a major outbreak in Germany due to its ability to express virulence characteristics of both enteroaggregative E. coli (EAEC) and EHEC [39]. Foods implicated in past EHEC outbreaks include ground meat, unpasteurised apple juices, raw milk, fermented hard salami and sprouted seeds [37, 40]. Environmental transmission of EHEC via contact with manure, animals and infected people has also been documented [41]. Although the detection of VTEC and E. coli O157:H7 in our samples may be of concern, it is noteworthy that no EHEC-related outbreak has ever been reported in Singapore, and that the possibility of an imported sporadic case cannot be ruled out.

The prevalence of Campylobacter spp. (5 \%) and Salmonella spp. (1\%) in this study was relatively low in comparison to that of other targeted organisms. In several high-income countries, both Campylobacter spp. and non-typhoidal Salmonella spp. are determined to be the leading causes for acute gastroenteritis (AGE) [20, 21, 23, $24,42]$. While hospitalisation due to campylobacteriosis is generally less common than that due to salmonellosis in the U.S. and the U.K., campylobacteriosis is more frequently encountered than salmonellosis among AGE hospitalised cases in Germany [21, 24, 42]. In the U.S., Campylobacter and Salmonella are estimated to be responsible for 15 and $35 \%$ of hospitalisations due to foodborne illness respectively (all age groups) [24]. In the U.K., it was estimated that about 9 to $18 \%$ of foodborne hospitalisations of all age groups were due to Campylobacter and about 33 to $48 \%$ were due to Salmonella [42]. In Germany, 35 and $20 \%$ of the AGE hospitalised cases were due to Campylobacter and Salmonella respectively [21]. The low identification rate of Salmonella spp. in this study suggests that this pathogen may not be a major cause of hospitalisation in adults. Globally, salmonellosis has been associated with the consumption of contaminated food such as meat, eggs, poultry, fish, peanut butter and spices, as well as contact with pets such as turtles, frogs and chicks [43]. Campylobacteriosis, on the other hand, has generally been linked to animal contact, cross-contamination of food, as well as the consumption of raw milk, unpasteurised cheese, and undercooked poultry [44]. As Salmonella and Campylobacter can result in severe complications and 
sometimes death among the vulnerable populations such as the young and elderly [43,44], continuous vigilance in the form of food safety education and surveillance efforts is required in order to safeguard public health.

The Vibrio cholerae isolate recovered in this study was found to be of serogroup O1 and biotype El Tor. Worldwide, $V$. cholerae serogroup $\mathrm{O} 1$ and serogroup $\mathrm{O} 139$ are recognised as the cause for cholera outbreaks [45]. The O1 serogroup consists of two biotypes, namely classical and El Tor [45]. The classical biotype was associated with pandemics prior to 1961 but was overtaken by the El Tor biotype thereafter [45]. Cholera is commonly linked to the consumption of contaminated water, ice and food, in particular seafood [46]. Between 2009 and 2013, the incidence of cholera in Singapore was between 0.02 and 0.08 per 100,000 population [5, 6, 47-49]. More than half of these cases were imported and $V$. cholerae serogroup $\mathrm{O} 1$ was identified as the most common serogroup responsible for cholera in Singapore [5, 6, 47-49]. Although the detection of Vibrio cholerae O1 El Tor may suggest a public health concern, it is worth mentioning that the incidence of cholera has always been low in Singapore. This is possibly due to the accessibility of potable water and sanitation infrastructures by the general public. Nevertheless, public health agencies should continue to monitor for signs of outbreaks and strive to maintain high standards of public hygiene and cleanliness.

It is noteworthy that there are several limitations in this preliminary study. The sample size was small and the samples were collected from a public hospital which may not be representative of the country. Due to the absence of medical history and epidemiological data from patients, it is difficult to determine the likely risk exposures and factors associated to these AGE cases, as well as to rule out cases of non-infectious diarrhoea. The lack of pathogen prevalence data from a healthy control group also makes it hard to assess whether the high prevalence of certain pathogens such as Aeromonas spp. were clinically significant. Furthermore, as adults are seldom admitted to hospitals for the treatment of diarrhoea in Singapore, the faecal samples obtained in this study might not truly reflect important aetiological agents affecting the community. Finally, the panel of pathogens targeted in our study does not represent an exhaustive list of pathogens that may be of public health interest. For instance, the screening of sapovirus, an important calicivirus also known to cause AGE, was not conducted in this study. The detection rates of sapovirus in stools were reported to reach levels as high as $9.2 \%$ in specimens collected from a community cohort in the United Kingdom [19]. Such findings suggest that the contribution of sapovirus to disease burden may be higher than previously thought. Although no local data are available on its importance in Singapore, sapovirus, which was previously known to affect mostly children, has recently increasingly been reported to be associated with infections and outbreaks among adults in other countries, including in Asia [4, 19, 50-53]. Thus, the contribution of sapovirus to the disease burden of AGE in Singapore may need to be investigated further in future studies.

\section{Conclusion}

Our preliminary findings suggest that pathogens causing non-notifiable foodborne diseases, such as norovirus, may contribute considerably to adult hospital attendances. However, as the samples analysed were obtained from a hospital, the data obtained may not be representative of the country as a whole. In order to better understand the epidemiology of AGE in Singapore, a larger study involving the analysis of faecal samples and risk exposure data collected from symptomatic and asymptomatic individuals in non-hospital settings may be beneficial to better characterise the epidemiology and transmission routes of AGE pathogens circulating in the community, and to better define priorities for their control. The screening of sapovirus and other pathogenic $E$. coli, such as enterotoxigenic $E$. coli, enteropathogenic $E$. coli, enteroaggregative $E$. coli, enteroinvasive $E$. coli and diffusely adherent $E$. coli could also be considered for future studies.

\section{Competing interests}

The authors declare that they have no competing interests.

\section{Authors' contributions}

LCN and TB developed the study design. TB prepared and submitted the bioethics documents for approval, and co-ordinated the collection of clinical samples required for this study. MLC, MY and SHPH co-ordinated the transfer of clinical samples, conducted the screening of 18 diarrheagenic pathogens in faecal samples using molecular assays and immunoassays, carried out the isolation and biochemical confirmation of bacterial pathogens, performed serological testing on Salmonella and Vibrio cholerae isolates, analysed sequences, performed the statistical analysis and drafted the manuscript. JSLK optimised in-house PCR protocols specifically for the detection of Aeromonas spp., Campylobacter spp., Salmonella spp. and V. cholerae. JSLK also performed the molecular characterisation of Vibrio cholerae and contributed technical advice on pathogenic E. coli. KTA optimised inhouse protocol for the detection of L. monocytogenes and contributed technical advice on molecular results. CCT, LCN, RAG and TB contributed technical advice and guidance on the study. $C C T$ commented on the manuscript. LCN, RAG and TB vetted the manuscript. All authors read and approved the final manuscript.

\section{Acknowledgement}

This research was supported by the Reinvestment Fund (RF), Ministry of Finance (MOF), Singapore.

\section{Author details \\ ${ }^{1}$ Environmental Health Institute, National Environment Agency, 11 Biopolis Way, \#04-03/04, Helios Block, Singapore 138667, Singapore. ${ }^{2}$ Saw Swee Hock School of Public Health, National University of Singapore, Tahir Foundation Building, 12 Science Drive 2, \#10-01, Singapore 117549, Singapore. ${ }^{3}$ London School of Hygiene \& Tropical Medicine, Keppel Street, London WC1E 7HT, UK. ${ }^{4}$ Department of Laboratory Medicine, Tan Tock Seng Hospital, 11 Jalan Tan Tock Seng, Singapore 308433, Singapore.}




\section{References}

1. Elliott EJ. Acute gastroenteritis in children. BMJ. 2007;334(7583):35-40.

2. Chow CM, Leung A, Hon K. Acute gastroenteritis: from guidelines to real life. Clin Exp Gastroenterol. 2010;3:97-112.

3. Flint JA, Van Duynhoven YT, Angulo FJ, DeLong SM, Braun P, Kirk M, et al. Estimating the burden of acute gastroenteritis, foodborne disease, and pathogens commonly transmitted by food: an international review. Clin Infect Dis. 2005:41(5):698-704.

4. Tam CC, Rodrigues LC, Viviani L, Dodds JP, Evans MR, Hunter PR, et al. Longitudinal study of infectious intestinal disease in the UK (IID2 study): incidence in the community and presenting to general practice. Gut. 2012;61(1):69-77.

5. Ministry of Health Singapore. Food-/water-borne diseases. In: Communicable Diseases Surveillance in Singapore 2013. 2014. https://www. moh.gov.sg/content/dam/moh_web/Publications/Reports/2014/ Communicable\%20Diseases\%20Surveillance\%20in\%20Singapore\%202013/ Food\%20Water\%20Borne\%20Diseases.pdf. Accessed 26 Jan 2016.

6. Ministry of Health Singapore. Food-/water-borne diseases. In: Communicable Diseases Surveillance in Singapore 2009. 2010. http://www. moh.gov.sg/content/dam/moh_web/Publications/Reports/2011/ Communicable\%20Diseases\%20Surveillance\%20in\%20Singapore\%202010/ Food\%20water-borne\%202010.pdf. Accessed 26 Jan 2016.

7. Ministry of Health Singapore. List of infectious diseases legally notifiable under the Infectious Diseases Act. 2014. http://www.moh.gov.sg/content/ moh_web/moh_corp_mobile/home/diseases_conditions/List_of_Infectious_ Diseases_Legally_Notifiable_under_the_Infectious_Diseases_Act.html. Accessed 26 Jan 2016

8. National Library Board Singapore. Tan Tock Seng Hospital (TTSH). In: singaporeinfopedia. 2004. http://eresources.nlb.gov.sg/infopedia/articles/SIP_ 70 2004-12-24.html. Accessed 26 Jan 2016.

9. Ministry of Health Singapore. Gastroenteritis (diarrhoea). 2015. https://www. moh.gov.sg/content/moh_web/home/costs_and_financing/HospitalBillSize/ gastroenteritis_diarrhoea.html. Accessed 26 Jan 2016.

10. Ministry of Health Singapore. Gastroenteritis (diarrhoea) with complications. 2015. https://www.moh.gov.sg/content/moh_web/home/costs and financing/HospitalBillSize/gastroenteritis_diarrhoeawithcomplications.html. Accessed 26 Jan 2016.

11. U.S. Food and Drug Administration. BAM Media M10: Alkaline Peptone Water. In: Bacteriological Analytical Manual, 8th Edition, Revision A, 1998 2001. http://www.fda.gov/Food/FoodScienceResearch/LaboratoryMethods/ ucm062995.htm. Accessed 26 Jan 2016

12. U.S. Food and Drug Administration. BAM Media M136: Shigella Broth. In: Bacteriological Analytical Manual, 8th Edition, Revision A, 1998. http://www. fda.gov/Food/FoodScienceResearch/LaboratoryMethods/ucm063628.htm. Accessed 26 Jan 2016

13. U.S. Food and Drug Adminstration. BAM: Shigella. http://mww.fda.gov/Food/ FoodScienceResearch/LaboratoryMethods/ucm070789.htm. Accessed 26 Jan 2016.

14. Wang G, Clark CG, Liu C, Pucknell C, Munro CK, Kruk TM, et al. Detection and characterization of the hemolysin genes in Aeromonas hydrophila and Aeromonas sobria by multiplex PCR. J Clin Microbiol. 2003;41(3):1048-54.

15. Hoshino K, Yamasaki S, Mukhopadhyay AK, Chakraborty S, Basu A, Bhattacharya SK, et al. Development and evaluation of a multiplex PCR assay for rapid detection of toxigenic Vibrio cholerae 01 and 0139. FEMS Immunol Med Microbiol. 1998:20(3):201-7.

16. Bharati K, Ganguly NK. Cholera toxin: a paradigm of a multifunctional protein. Indian J Med Res. 2011;133(2):179-87.

17. Ministry of Health Singapore. Epidemiology and control of food poisoning outbreaks in Singapore, 2009-2011. In: Epidemiol News Bull. 2012. http:// www.moh.gov.sg/content/dam/moh_web/Statistics/Epidemiological_News_ Bulletin/2012/ENB03Q_12.pdf. Accessed 26 Jan 2016.

18. Ministry of Health Singapore. Epidemiology of childhood infectious gastroenteritis in Singapore: how effectively can we control it? Epidemiol News Bull. 2005;38(3):51-3.

19. Tam CC, O'Brien SJ, Tompkins DS, Bolton FJ, Berry L, Dodds J, et al. Changes in causes of acute gastroenteritis in the United Kingdom over 15 years: microbiologic findings from 2 prospective, population-based studies of infectious intestinal disease. Clin Infect Dis. 2012;54:1275-86.

20. Hall G, Kirk MD, Becker N, Gregory JE, Unicomb L, Millard G, et al. Estimating foodborne gastroenteritis. Australia Emerg Infect Dis. 2005;11(8):1257-64.

21. Jansen A, Stark K, Kunkel J, Schreier E, Ignatius R, Liesenfeld O, et al. Aetiology of community-acquired, acute gastroenteritis in hospitalised adults: a prospective cohort study. BMC Infect Dis. 2008;8(1):143.
22. Scallan E, Griffin PM, Angulo FJ, Tauxe RV, Hoekstra RM. Foodborne illness acquired in the United States - unspecified agents. Emerg Infect Dis. 2011 $17(1): 16-22$.

23. Scallan E, Hoekstra RM, Angulo FJ, Tauxe RV, Widdowson M-A, Roy SL et al. Foodborne illness acquired in the United States - major pathogens. Emerg Infect Dis. 2011:17(1):7-15.

24. U.S. Centers for Disease Control and Prevention. CDC estimates of foodborne illness in the United States. 2011. http://www.cdc.gov/ foodborneburden/2011-foodborne-estimates.html. Accessed 26 Jan 2016.

25. Phillips G, Tam C, Rodrigues L, Lopman B. Risk factors for symptomatic and asymptomatic norovirus infection in the community. Epidemiol Infect. 2011; 139(11):1676-86.

26. Repp KK, Keene WE. A point-source norovirus outbreak caused by exposure to fomites. J Infect Dis. 2012;205(11):1639-41.

27. Marks P, Vipond I, Regan F, Wedgwood K, Fey R, Caul E. A school outbreak of Norwalk-like virus: evidence for airborne transmission. Epidemiol Infect. 2003;131(01):727-36.

28. Baert L, Mattison K, Loisy-Hamon F, Harlow J, Martyres A, Lebeau B, et al. Review: norovirus prevalence in Belgian, Canadian and French fresh produce: a threat to human health? Int J Food Microbiol. 2011;151(3):261-9.

29. Bitler E, Matthews J, Dickey B, Eisenberg J, Leon J. Norovirus outbreaks: a systematic review of commonly implicated transmission routes and vehicles. Epidemiol Infect. 2013;141(08):1563-71.

30. Tang MB, Chen CH, Chen SC, Chou YC, Yu CP. Epidemiological and molecular analysis of human norovirus infections in Taiwan during 2011 and 2012. BMC Infect Dis. 2013;13:338.

31. Patel MM, Widdowson M-A, Glass Rl, Akazawa K, Vinjé J, Parashar UD. Systematic literature review of role of noroviruses in sporadic gastroenteritis. Emerg Infect Dis. 2008;14(8):1224-31.

32. Desai R, Hembree CD, Handel A, Matthews JE, Dickey BW, McDonald S, et al. Severe outcomes are associated with genogroup 2 genotype 4 norovirus outbreaks: a systematic literature review. Clin Infect Dis. 2012;55(2):189-93.

33. Phillips G, Lopman B, Tam CC, Iturriza-Gomara M, Brown D, Gray J. Diagnosing norovirus-associated infectious intestinal disease using viral load. BMC Infect Dis. 2009;9(1):63.

34. Neyts K, Huys G, Uyttendaele M, Swings J, Debevere J. Incidence and identification of mesophilic Aeromonas spp. from retail foods. Lett Appl Microbiol. 2000:31(5):359-63.

35. Surek M, Vizzotto BS, Souza EM, Pedrosa FDO, Dallagassa CB, Farah SM, et al. Identification and antimicrobial susceptability of Aeromonas spp. isolated from stool samples of Brazilian subjects with diarrhea and healthy controls. Med Microbiol. 2010;59(3):373-4

36. Tompkins D, Hudson M, Smith H, Eglin R, Wheeler J, Brett M, et al. A study of infectious intestinal disease in England: microbiological findings in cases and controls. Commun Dis Public Health. 1999;2(2):108-13.

37. Nataro JP, Kaper JB. Diarrheagenic Escherichia coli. Clin Microbiol Rev. 1998; 11(1):142-201.

38. Barlow RS, Mellor GE. Prevalence of enterohemorrhagic Escherichia coli serotypes in Australian beef cattle. Foodborne Pathog Dis. 2010;7(10): 1239-45.

39. Brzuszkiewicz E, Thürmer A, Schuldes J, Leimbach A, Liesegang H, Meyer F$D$, et al. Genome sequence analyses of two isolates from the recent Escherichia coli outbreak in Germany reveal the emergence of a new pathotype: Entero-Aggregative-Haemorrhagic Escherichia coli (EAHEC). Arch Microbiol. 2011;193(12):883-91.

40. Feng P. Pathogenic Escherichia coli group. In: Lampel KA, Al-Khaldi S, Cahill SM, editors. Bad bug book, foodborne pathogenic microorganisms and natural toxins. 2nd edition, 2012: 68

41. Ferens WA, Hovde CJ. Escherichia coli O157: H7: animal reservoir and sources of human infection. Foodborne Pathog Dis. 2011;8(4):465-87.

42. Tam CC, Larose T, O'Brien SJ. Identifying the proportion of foodborne disease in the UK and attributing foodborne disease by food commodity, Project B18021 (FS231043). 2014.

43. Hammack T. Salmonella species. In: Lampel KA, Al-Khaldi S, Cahill SM, editors. Bad bug book, foodborne pathogenic microorganisms and natural toxins. 2nd ed. USA; Food \& Drug Administration. 2012: 12

44. Foley S, Nayak R. Campylobacter jejuni. In: Lampel KA, Al-Khaldi S, Cahill SM, editors. Bad bug book, foodborne pathogenic microorganisms and natural toxins. 2nd ed. USA; Food \& Drug Administration; 2012. p. 16-17.

45. O'shea YA, Reen FJ, Quirke AM, Boyd EF. Evolutionary genetic analysis of the emergence of epidemic Vibrio cholerae isolates on the basis of comparative 
nucleotide sequence analysis and multilocus virulence gene profiles. J Clin Microbiol. 2004;42(10):4657-71.

46. DePaola A, Jones JL. Vibrio cholerae serogroups $\mathrm{O} 1$ and O139. In: Lampel KA, Al-Khaldi S, Cahill SM, editors. Bad bug book, foodborne pathogenic microorganisms and natural toxins. 2nd ed. 2012. p. 38-41.

47. Ministry of Health Singapore. Food-/water-borne diseases. In: Communicable Diseases Surveillance in Singapore 2010. 2011. http:/www. moh.gov.sg/content/dam/moh_web/Publications/Reports/2012/ Communicable\%20Diseases\%20Surveillance\%20in\%20Singapore\%202011/ Food-Water-Borne\%20Diseases.pdf. Accessed 26 Jan 2016.

48. Ministry of Health Singapore. Food-Mater-Borne Diseases. Communicable Diseases Surveillance in Singapore 2011. 2012.

49. Ministry of Health Singapore. Food-/water-borne diseases. In: Communicable Diseases Surveillance in Singapore 2012. 2013. https:/www. moh.gov.sg/content/dam/moh_web/Publications/Reports/2013/FoodWater-Borne\%20Diseases.pdf. Accessed 26 Jan 2016.

50. Svraka S, Vennema H, van der Veer B, Hedlund K-O, Thorhagen M, Siebenga $J$, et al. Epidemiology and genotype analysis of emerging sapovirusassociated infections across Europe. J Clin Microbiol. 2010;48(6):2191-8.

51. Nidaira M, Taira K, Kato T, Arakaki E, Kyan H, Takara T, et al. Phylogenetic analysis of sapovirus detected from an outbreak of acute gastroenteritis on Ishigaki island (Okinawa prefecture, Japan) in 2012. Jpn J Infect Dis. 2014;67:141-3.

52. Wang G, Shen Z, Qian F, Li Y, Yuan Z, Zhang J. Genetic diversity of sapovirus in non-hospitalized adults with sporadic cases of acute gastroenteritis in Shanghai, China. J Clin Virol. 2014;59(4):250-4.

53. Wu F-T, Oka T, Takeda N, Katayama K, Hansman GS, Muo C-H, et al. Acute gastroenteritis caused by GI/2 sapovirus, Taiwan, 2007. Emerg Infect Dis. 2008;14(7):1169-71.

54. Moreno Y, Hernández M, Ferrús MA, Alonso JL, Botella S, Montes R, et al. Direct detection of thermotolerant Campylobacters in chicken products by PCR and in situ hybridization. Res Microbiol. 2001;152(6):577-82

55. Chiu CH, Ou JT. Rapid identification of Salmonella serovars in feces by specific detection of virulence genes, invA and spvC, by an enrichment broth culture-multiplex PCR combination assay. J Clin Microbiol. 1996; 34(10):2619-22.

56. Liu D, Lawrence ML, Wiedmann M, Gorski L, Mandrell RE, Ainsworth AJ, et al. Listeria monocytogenes subgroups IIIA, IIIB, and IIIC delineate genetically distinct populations with varied pathogenic potential. J Clin Microbiol. 2006:44(11):4229-33.

57. Neogi S, Chowdhury N, Asakura M, Hinenoya A, Haldar S, Saidi S, et al. A highly sensitive and specific multiplex PCR assay for simultaneous detection of Vibrio cholerae, Vibrio parahaemolyticus and Vibrio vulnificus. Lett Appl Microbiol. 2010;51(3):293-300.

58. Rivera IN, Chun J, Huq A, Sack RB, Colwell RR. Genotypes associated with virulence in environmental isolates of Vibrio cholerae. Appl Env Microbiol. 2001;67(6):2421-9.

59. Imani FA, Iman ID, Hosseini DR, Karami A, Marashi S. Design of a multiplex PCR method for detection of toxigenic-pathogenic in Vibrio cholerae. Asian Pac J Trop Med. 2013;6(2):115-8.

\section{Submit your next manuscript to BioMed Central and we will help you at every step:}

- We accept pre-submission inquiries

- Our selector tool helps you to find the most relevant journal

- We provide round the clock customer support

- Convenient online submission

- Thorough peer review

- Inclusion in PubMed and all major indexing services

- Maximum visibility for your research

Submit your manuscript at www.biomedcentral.com/submit

) Biomed Central 